https://doi.org/10.37208/tgn27222

\section{A brief consideration of the later prehistoric appearance and possible significance of the great auk (Pinguinus impennis) in the Covesea Caves of north-east Scotland}

\author{
A. Fitzpatrick ${ }^{1}$, J. Bond ${ }^{1}$, L. Büster ${ }^{2} \&$ I. Armit ${ }^{2}$ \\ ${ }^{1}$ Department of Archaeological and Forensic Sciences, \\ University of Bradford, Richmond Road, Bradford, \\ West Yorkshire BD7 1DP \\ ${ }^{2}$ Department of Archaeology, University of York, \\ King's Manor, Exhibition Square, York YO1 7EP \\ E-mail: a.l.fitzpatrick@bradford.ac.uk
}

The Covesea Caves are located in north-east Scotland, on the southern coast of the Moray Firth. They comprise several individual sites that were used at various times from the Early Neolithic to the Roman Iron Age for mortuary activity (Armit \& Büster, 2020; Büster, 2015): they include Covesea Caves 1 and 2 (disturbed by amateur excavations during the 1960s); and the Laird's Stables, which are the subject of current excavations by a team from the universities of York and Bradford (Büster \& Armit, 2016, 2019); and the Sculptor's Cave, which was originally excavated in the 1920 s and 1930 s (Benton, 1931), revisited in the 1970s (Shepherd \& Shepherd, 1979) and finally published as part of the Sculptor's Cave Project (Armit \& Büster, 2020).

In total, 8,262 individual faunal bones have been identified and analysed for the Covesea Caves Project (from the Sculptor's Cave; Caves 1 and 2; and the Laird's Stables). $25 \%$ of this total has been identified as avian, with 488 bones (6\%) belonging to species of seabird.

Within these seabird assemblages, a total of 30 individual bones have been identified as great auk (Pinguinus impennis), a now-extinct, flightless bird once found throughout the North Atlantic. The inability to fly rendered the Great Auk easy prey, and it was often hunted for its meat and fat (Svanberg, 2014). Overexploitation of the great auk was not due to subsistence alone, however. As populations dwindled, natural history collectors and museums eagerly hunted these seabirds for display of their eggs and skin (Minteer et al., 2014).

The great auk originally inhabited regions across the North Atlantic, although remains have been found as far south as Florida and Bermuda. It was particularly widespread throughout the Scottish islands and coastal areas, with the remote islands used mainly for breeding. As such, many excavations in areas such as the Orkney
Islands and Shetland have recovered numbers of great auk bones (Forrester et al., 2007).

This Short Note describes the distribution and composition of the great auk assemblage found within the Covesea Caves, and discusses its significance.

Species identification was undertaken following the general methods and guidelines used by the zooarchaeological database of the North Atlantic Biocultural Organisation (McGovern et al., 2008). For comparison of most osteological specimens, the archaeofaunal reference collection at the University of Bradford was consulted. In addition, the avian anatomical collection at the Natural History Museum, Tring, England, and Cohen \& Serjeantson (1986) were used to confirm the identity of avian species.

Remains of the great auk have been identified in three of the four caves investigated. However, only one individual specimen was found at both Covesea Cave 1 and the Sculptor's Cave, with the overwhelming majority deriving from Covesea Cave 2. Preservation of the remains overall was consistently excellent, with little to no weathering or fragmentation. One recovered specimen represented the remains of an articulated "leg", including tibiotarsus, femur, fibula, and tarsometatarsus (Fig. 1). In addition, some bones still had the remains of soft tissue adhering to them (Fig. 2). Unfortunately, most of the great auk fragments derived from unstratified or mixed deposits (Table 1) but in Covesea Cave 2 five fragments were attributed to stratified contexts of Neolithic/Bronze Age $(\mathrm{N}=2)$ or Medieval/Post-Medieval date $(\mathrm{N}=3)$.

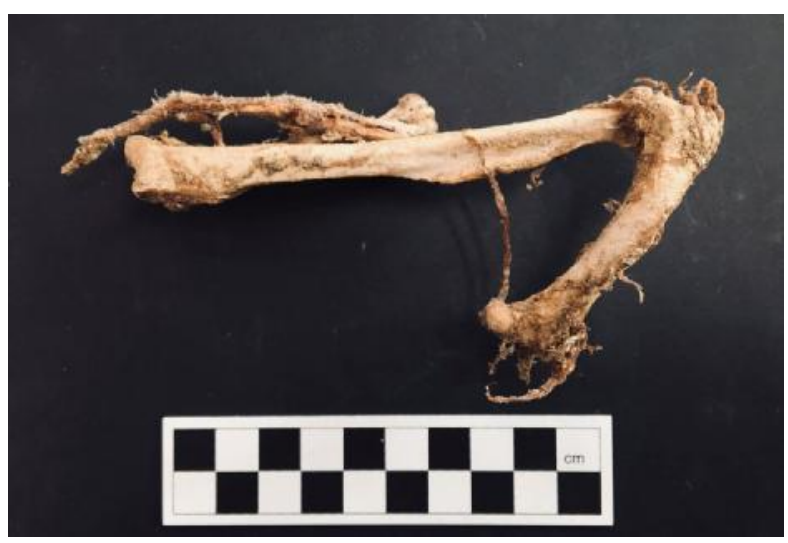

Fig. 1. An articulated great auk (Pinguinus impennis) leg fragment recovered at the Covesea Caves, north-east Scotland. Left to right: tarsometatarsus, fibula, tibiotarsus, and femur (Trench 4, Context 406, Covesea Cave 2). (Photo: A. Fitzpatrick)

All of the great auk remains could be identified to skeletal element, with limb bones (74\%), particularly humeri, dominating the assemblage (Fig. 3); there were no crania. None of the bones displayed evidence of butchery. 


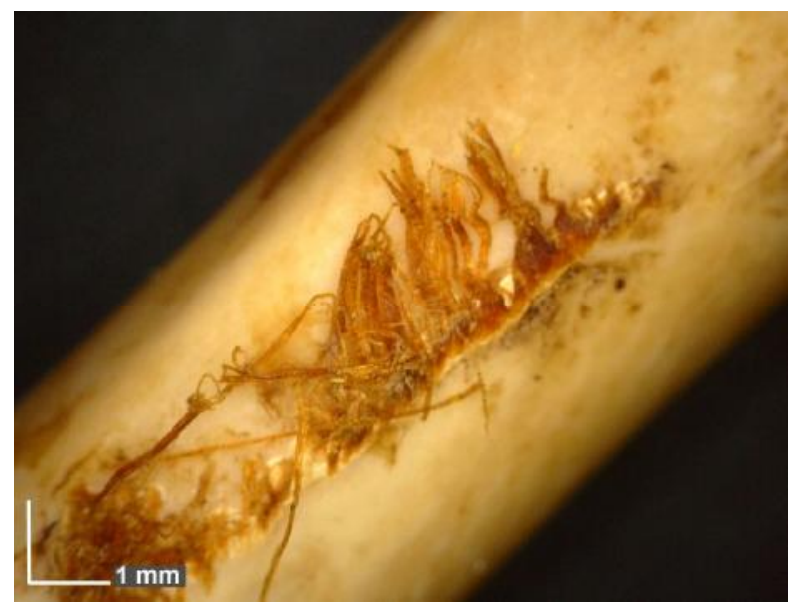

Fig. 2. Detail view of soft tissue remains on great auk (Pinguinus impennis) femur recovered at the Covesea Caves, north-east Scotland (unstratified context, Covesea Cave 2). (Photo: A. Fitzpatrick)

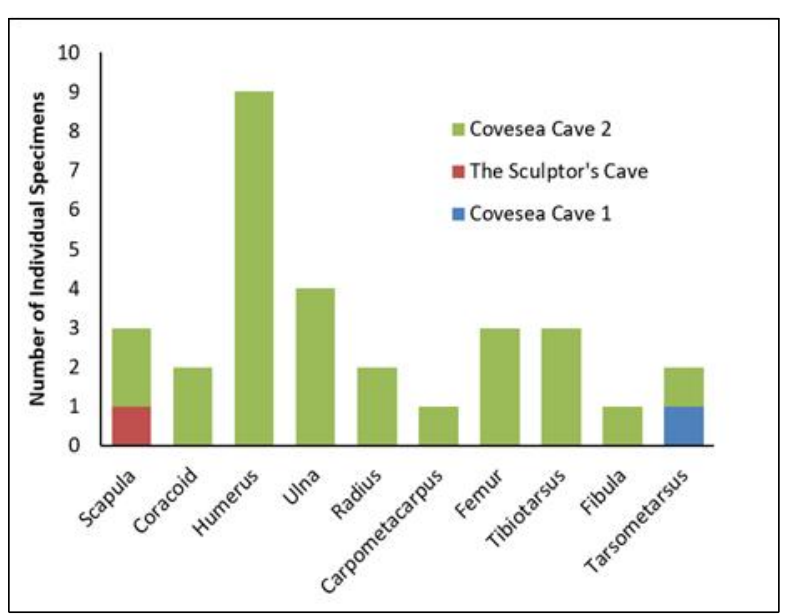

Fig. 3. Great auk (Pinguinus impennis) assemblage by skeletal element recovered at the Covesea Caves, north-east Scotland.

\begin{tabular}{lll}
\hline Site & Phase & Number of Individual Specimens \\
\hline Covesea Cave 1 & Unstratified/Mixed & 1 \\
Covesea Cave 2 & Neolithic/Bronze Age & 2 \\
& Medieval/Post-Medieval & 3 \\
& Unstratified/Mixed & 23 \\
The Sculptor's Cave & Unstratified/Mixed & 1 \\
\hline Total & & $\mathbf{3 0}$ \\
\hline
\end{tabular}

Table 1. Location and dates of the Covesea Caves, north-east Scotland great auk (Pinguinus impennis) assemblage.

Clearly, there is precedent for considering the great auk as a possible subsistence food resource, which seems to have been the case until its extinction in 1844 (Serjeantson, 2001). Evidence for the consumption of great auk in prehistory exists across the British Isles, with many sites indicating a decline during the Late Iron Age, perhaps already as the result of overexploitation (Forrester et al., 2007, Best \& Mulville, 2013).

At least three of the caves (the Sculptor's Cave, Cave 1 and Cave 2) appear to have been used for mortuary activity at various times between the Early Neolithic and the Roman Iron Age. Faunal remains must be considered as potentially associated with funerary rites or related ritual activities which may have occurred concurrently with the deposition of human bones. Of course, subsistence and ritual are not mutually exclusive, as is evident from ritual feasting and consumption being a common practice in both the archaeological and ethnographic records (Fitzpatrick, 2007; Hayden, 2014; Madgwick \& Mulville, 2015).

It is possible that the great auk was utilised in ritualistic activity apart from consumption. At Broxmouth hillfort in East Lothian, for example (a site which has produced the largest surviving faunal assemblage in mainland Scotland), cranial elements of a great auk were found adjacent to a near-complete horse skull, within an apparently structured deposit of 182 animal bones in a pit outside the south-west entrance to the Phase $3 \mathrm{~b}$ hillfort (Armit \& McKenzie 2013; Salvagno, 2013).
Perhaps the most striking ritual deposition of this type from the Scottish Iron Age is the placement of the complete head of a great auk (represented by its cranium and beak) behind the wall of Wheelhouse 2 at Cnip during its construction; a group of seven other great auk bones (probably from a single specimen) were also recovered from a single floor deposit in Structure 4 at the same site (Armit, 2006). The former example, which was one of a series of unusual deposits behind the wheelhouse wall, is interpreted as a foundation deposit associated with construction of the building.

It remains possible, of course, that, rather than reflecting either subsistence or ritual activity, the great auk remains from the Covesea Caves represent natural deposition. After all, the Covesea Caves are located on the coast of north-east Scotland, which would be a likely habitat for the species. The lack of butchery marks, as well as the absence of cranial elements, could also suggest this.

We would like to thank Dr Jerry Herman (Vertebrates Collection) and Dr Matthew Knight (Early Prehistory Collection) for supervising comparative analysis at the Collections Centre of the National Museum of Scotland in Edinburgh. The work described herein has been supervised by Dr. Julie Bond and Dr. Jo Buckberry at the University of Bradford, and Dr. Lindsey Büster and Professor Ian Armit at the University of York. It forms part of the Covesea Caves Project (www,coveseacavesproject.wordpress.com). Funding for this research was provided by the Glasgow Natural History Society Professor Blodwen Lloyd Binns 
Bequest, the Prehistoric Society, and the Society of Antiquaries of Scotland. Prior collection of samples took place during the Covesea Caves Project 2018 excavation season, with help from Danny Shaw, Rachael Kershaw, Rob Harman, Mike Offley, and Kevin Rutherford, and was funded by Historic Environment Scotland and Aberdeenshire Council.

\section{REFERENCES}

Armit, I. (2006). Anatomy of an Iron Age Roundhouse: the Cnip Wheelhouse Excavations, Lewis. Society of Antiquaries of Scotland, Edinburgh.

Armit, I. \& Büster, L. (2020). Darkness Visible: the Sculptor's Cave, Covesea, from the Bronze Age to the Picts. Society of Antiquaries of Scotland, Edinburgh.

Armit, I. \& McKenzie, J. (2013). An Inherited Place: Broxmouth Hillfort and the South-east Scottish Iron Age. Society of Antiquaries of Scotland, Edinburgh.

Benton, S. (1931). The excavation of the Sculptor's Cave, Covesea, Morayshire. Proceedings of the Society of Antiquaries of Scotland 65, 177-216.

Best, J. \& Mulville, J. (2013). Between the sea and sky: the archaeology of avian resource exploitation in Scottish island environments. In: Daire, M., Dupont, C., Baudry, A., Billard, C., Large, J., Lespez, L. et al. (Editors). Ancient Maritime Communities and the Relationship between People and Environment along the European Atlantic Coasts, pp. 417-426. Archaeopress, Oxford.

Büster, L. \& Armit, I. (2016). The Covesea Caves Project Fieldwork 2015. Data Structure Report, University of Bradford.

Büster, L. \& Armit, I. (2019). The Covesea Caves Project Fieldwork 2018. Data Structure Report, University of Bradford.

Büster, L. (2015). The Covesea Caves Project. Research and Projects. https://www.socantscot.org/researchproject/the-covesea-caves-project/ Accessed 15th October 2019.

Cohen, A. \& Serjeantson, D. (1986). A Manual for the Identification of Bird Bones from Archaeological Sites. Alan Cohen, London.

Fitzpatrick, A.P. (2007). The fire, the feast, and the funeral: Late Iron Age mortuary practices in southeastern England. Revue du Nord 11, 123-142.

Forrester, R.W., Andrews, I.J., McInerny, C.J., Murray, R.D., McGowan, R.Y., Zonfrillo, B. et al. (2007). The Birds of Scotland. The Scottish Ornithologists' Club, Aberlady.

Hayden, B. (2014). The Power of Feasts: from Prehistory to the Present. Cambridge University Press, Cambridge. https://doi.org/10.1017/CBO9781107337688

Madgwick, R. \& Mulville, J. (2015). Feasting on forelimbs: conspicuous consumption and identity in later prehistoric Britain. Antiquity 89(345), 629-644. https://doi.org/10.15184/aqy.2015.24

McGovern, T., Perdikaris, S., Woollett, J., Amundsen, C., Krivogorskaya, Y., Hambrecht, G. et al. (2008). NABONE Zooarchaeological Database: Recording System Codes. https://www.nabohome.org/products/manuals/fishb one/NABONE9thEdition.pdf

Minteer, B.A., Collins, J.O., Love, K.E. \& Puschendorf, R. (2014). Avoiding (re)extinction. Science 344, 260-261. https://doi.org/10.1126/science.1250953

Salvagno, L. (2013). Bird bone. In: Armit, I. \& McKenzie, J. (Editors). An Inherited Place: Broxmouth Hillfort and the South-East Scottish Iron Age, pp. 471-473. Society of Antiquaries of Scotland, Edinburgh.

Serjeantson, D. (2001). The great auk and the gannet: a prehistoric perspective on the extinction of the great auk. International Journal of Osteoarchaeology 11, 43-55. https://doi.org/10.1002/oa.545

Shepherd, I.A.G. \& Shepherd, A.N. (1979). The Sculptor's Cave, Covesea, Moray. Discovery and Excavation in Scotland 1979, 14.

Svanberg, I. (2014). Great Auk. In: Hund, A.J. (Editor). Antarctica and the Arctic Circle: A Geographic Encyclopedia of the Earth's Polar Regions, p. 311. CA: ABC-CLIO, Santa Barbara, USA. 